Fundamental British Values and Citizenship Education: tensions between national and global perspectives

Hugh Starkey

Department of Curriculum, Pedagogy and Assessment UCL Institute of Education,

London, UK

UCL Institute of Education

20 Bedford Way

GB- LONDON WC1H 0AL

h.starkey@ucl.ac.uk

Tel: 02079115507

Website: https://iris.ucl.ac.uk/iris/browse/profile?upi=HWSTA61

Hugh Starkey is Professor of Citizenship and Human Rights Education at UCL Institute of Education, London. His research focuses on education for democratic citizenship, human rights and social justice in a globalising world. He is founding co-director of the International Centre for Education for Democratic Citizenship and editor of the London Review of Education. 
and global perspectives Geografiska Annaler: Series B, Human Geography. Paper as accepted.

\section{Fundamental British Values and Citizenship Education: tensions between national and global perspectives}

This article discusses the tensions between the development of citizenship education in England since the 1990s and a more recent obligation on schools to promote Fundamental British Values (FBVs). The foundational and enduringly influential Crick Report (1998) that elaborated a rationale and detailed programme of study for citizenship education has a strong emphasis on political literacy that encourages acts of citizenship at scales from the very local to the global. A formal 2007 curriculum review of Citizenship advocated the framing of 'identity and diversity: living together in the UK' providing a locus for exploring multiple and flexible identities and cosmopolitan perspectives. However, the obligation on schools in England since 2014 to promote Fundamental British Values can be read as an attempt to reinstate the national. The policy shift from political literacy promoted in Citizenship to a focus on fundamental British values follows earlier attempts to promote a depoliticised values education. Previous empirical studies illustrate ways in which young people may acknowledge and respect local, national and cosmopolitan citizenship and identities. The UNICEF UK Rights Respecting Schools Award programme resists the nationalist agenda of Fundamental British Values by encouraging schools to promote the universalist UN Convention on the Rights of the Child as their guiding statement of values. The article concludes that the tensions discussed mirror those made manifest in the Brexit process.

Keywords: citizenship education; civic education; Fundamental British Values (FBVs); cosmopolitan citizenship; Rights Respecting Schools Award (RRSA); human rights 
and global perspectives Geografiska Annaler: Series B, Human Geography. Paper as accepted.

\section{Introduction}

At the turn of the $21^{\text {st }}$ century a new subject of Citizenship was introduced to the school curriculum in England $^{1}$ (Crick, 2000, 2003; Jerome, 2012). Since the heyday of nation building and state formation in the $19^{\text {th }}$ century, citizenship education has been instrumentalised by governments to promote commitment to a nation-state (Dewey, 1916; Green, 1990, 2013). Across the world, citizenship education requires students to learn about and to identify with a particular nation that has salience above all others (Nussbaum, 2012). The curriculum or programme of study often includes respecting national symbols such as flags and anthems, venerating a national constitution and recognising the alignment of nation with territory (Torney-Purta et al., 1999; Kymlicka, 2003).

This article explores the tensions between the curriculum subject of Citizenship in England, which is a locus for exploring issues of human rights and identities, and the obligation since 2014 for schools to promote Fundamental British Values (FBVs). Education for cosmopolitan citizenship, exemplified in UNICEF UK's Rights Respecting Schools programme, is contrasted with the security-focused and narrowly nationalistic Fundamental British Values agenda that risks marginalising teachers of Citizenship. The tension over the curriculum in some ways mirrors the split revealed by the 2016 UK referendum on Europe that can be read as a struggle between closed (national) versus open (cosmopolitan) worldviews or ideologies (Wheatley, 2016).

\section{Citizenship Education in England}

\footnotetext{
${ }^{1}$ There is no UK-wide curriculum. Each constituent nation has its own education system.
} 
and global perspectives Geografiska Annaler: Series B, Human Geography. Paper as accepted.

Citizenship Education in England was comprehensively defined in the report of the Advisory Group on Citizenship often referred to as the Crick Report after its chair, the political philosopher Bernard Crick. The report recognised the contribution the subject could and should make to discussions of what it means to be a citizen of the UK in a globalising world.

a main aim for the whole community should be to find or restore a sense of common citizenship, including a national identity that is secure enough to find a place for the plurality of nations, cultures, ethnic identities and religions long found in the United Kingdom. Citizenship education creates common ground between different ethnic and religious identities (QCA, 1998, 17).

Whilst the report acknowledges that there are numerous ethnic, cultural and religious identities in the UK, it leaves ambiguous whether individuals can have multiple and complex identities.

The programme of study resulting from the Crick Report in fact lacked reference to national institutions such as the flag or the Head of State that other jurisdictions such as France or USA consider to be fundamental (Osler and Starkey, 2001; 2009). It did, however, contain a very clear steer as to what it called the values and dispositions to be promoted by teachers. These were defined as including: concern for the common good, for human rights and for the environment; commitment to equal opportunities including gender equality, active citizenship and voluntary service; belief in human dignity and equality; respect for the rule of law; determination to act justly (Qualifications and Curriculum Authority, 1998, 44).

The Crick Report effectively determined the pedagogical model to be implemented through citizenship education. It was to be based on a constructivist theory of knowledge. Writing as the chair of the Advisory Group in a formal letter published as an appendix to the report and intended to differentiate citizenship education from 
and global perspectives Geografiska Annaler: Series B, Human Geography. Paper as accepted.

Personal, Social and Health Education (PSHE), Crick argued: 'Talk, discussion and debate are the bases of social responsibility and intercourse and the grounding and practice of active citizenship' (Qualifications and Curriculum Authority, 1998, 64). In other words, the pedagogical model is, following Dewey (1916) amongst others, that democracy is built by communicating and exchanging information on the basis of equal entitlement to contribute. This is in contrast to a top down transmission model of citizenship education, what Freire (1970) called 'banking' education. Such a model promotes a normative and conformist view of national identity. By contrast, the Crick Report model of citizenship education, based on building knowledge together, rather than transmitting specific official knowledge, requires teachers to promote questioning and critical thinking and students to bring their own realities to their studies and deliberations.

The Crick Report's constructivist model of citizenship education allows for contributions from students of different ethnic and national backgrounds in developing new understandings of living together in a democracy. In downplaying national symbols and institutions it opens up the possibility of decoupling citizenship and nationality (Osler and Starkey, 2005). This perspective, acknowledging multiple identities and the realities of flexible citizenship (Ong, 1999, 2004) was given some official recognition in the publication of a curriculum review recommending a new strand of citizenship education called 'identity and diversity: living together in the UK' (Department for Education and Skills, 2007). The approach was to include 'critical thinking about ethnicity, religion and "race"' as well as an 'explicit link to political issues and values'. In other words it recognised Citizenship as a site of political education and critical thinking. 
and global perspectives Geografiska Annaler: Series B, Human Geography. Paper as accepted.

This article explores the tensions between the explicitly political aims of citizenship education in England and a normative injunction to promote Fundamental British Values that, although politically motivated, reduces the scope for engaging with political issues (Elton-Chalcraft et al., 2017). Although the Citizenship programme of study in the national curriculum for England is typical in avoiding party political conflicts (Staeheli and Hammett, 2013), it nonetheless does provide opportunities to discuss and explore issues of identity (Gutmann, 2003). Given that England, alongside all the other major democracies, is a broadly multicultural nation whose citizens identify with many cultures young people whose feelings of belonging may encompass locales in several continents may understandably resist attempts to promote a narrowly nationalistic view of citizenship (Osler and Starkey, 2003; 2005).

The introduction of citizenship education in England was in many respects an experiment (Jerome, 2012). It provided an explicitly political framework that contrasts with other depoliticised and colour-blind attempts to promote discussion of values in the curriculum (Halstead and Taylor, 2002; Haydon, 2007). Approaches to values in the curriculum may be liberal in emphasising individual choices and responsibilities. This is the case with character education where individual flourishing is understood as the basis of a flourishing society where social tensions can be overcome by neighbourliness (Arthur, 2003). Citizenship, on the other hand acknowledges injustice, and the need to address inequalities through political action both within nations and in the increasingly salient sphere of transnational institutions (Banks, 2017). The introduction of Citizenship opened up a space for developing a theory and practice of global citizenship education (Oxfam, 2006), also conceptualised as education for cosmopolitan citizenship (Osler and Starkey, 2003). The practice of citizenship education in a globalised context 
and global perspectives Geografiska Annaler: Series B, Human Geography. Paper as accepted.

has been developed in thousands of schools in England that have adopted an NGOinitiated project called the Rights Respecting Schools Award that asserts a commitment to global and cosmopolitan citizenship based on placing international human rights standards the at the centre of the curriculum.

\section{Citizenship and Security Agendas}

Heightened government concerns about terrorism in the first decades of the $21^{\text {st }}$ century led to pressures on the education system to contribute to security agendas. Initially there was a concern for education to promote community cohesion (Home Office, 2001; Wood, 2016). Following the London bombings of 2005, all public bodies, including schools, have been required to support the security services in the anti-radicalisation 'Prevent' agenda. Whilst there is an important and legitimate role for schools in supporting security, the security agenda is driven from outside the education service by those with little professional understanding of schools. Whilst citizenship education evolved to meet the challenges of violent and anti-democratic ideologies through a focus on the positive liberal agendas of respect for human rights and open debate, it appeared to be side-lined when in 2014 a Conservative Secretary of State for Education obliged schools to promote the new and contentious construct of Fundamental British Values.

The phrase ‘fundamental British values' (FBVs) first appeared in a Home Office command paper on the anti-terrorist Prevent strategy (Richardson and Bolloten, 2014). In her foreword, the then Home Secretary Theresa May stated that the Government would not work with extremist organisations that reject 'our values of universal human rights, equality before the law, democracy and full participation in our society' (UK 
and global perspectives Geografiska Annaler: Series B, Human Geography. Paper as accepted.

Government Home Department, 2011, 1). It is notable that this formulation of 'our values' includes universal human rights. However, the civil servants who drafted the command paper itself opted to avoid the phrase 'universal human rights', perhaps as not distinctively British enough, and instead paraphrased the concept rather inadequately as: 'democracy, the rule of law, individual liberty and mutual respect and tolerance of different faiths and beliefs' (UK Government Home Department, 2011 p35 and p107).

The phrase 'fundamental British values' was adopted by the Department for Education, initially in a statement of teacher standards and subsequently in advice and guidance on the standard for all schools to promote 'SMSC' namely the spiritual, moral, social and cultural development of pupils. The standard is met when a school 'actively promotes the fundamental British values of democracy, the rule of law, individual liberty, and mutual respect and tolerance of those with different faiths and beliefs' (Department for Education, 2014, 6). Although the aims of school education had included promoting SMSC since the 1988 Education Act that introduced the national curriculum for England, the 2014 guidance was enforced by being included in the inspection regime as a priority area of concern (Richardson, 2015). The justification for compelling schools to promote FBVs was the inclusion of schools as public bodies in the holistic anti-extremism Prevent strategy.

Significantly, the Department for Education insisted that fundamental British values were to be promoted not through Citizenship, where they could be discussed and debated, but rather through a whole school ethos. From 2014, inspectors judge schools on the extent to which they promote the spiritual, moral, social and cultural development of their students, and they particularly evaluate the extent to which schools 
and global perspectives Geografiska Annaler: Series B, Human Geography. Paper as accepted.

specifically promote and teach Fundamental British Values (Department for Education, 2014; Richardson, 2015).

A focus on Fundamental British Values (FBVs) appears as a coercive attempt to require schools to privilege a pre-determined national narrative over a perspective that includes the local and the global and allows space for discussing different experiences and traditions of the national narrative (Elton-Chalcraft et al., 2017). One of the key concepts promoted as FBVs, tolerance, may appear to be a universal value, but in this context it signifies an ideological commitment to reduce political debate and impose normative views of citizenship (Staehili, 2011). Education for cosmopolitan citizenship, on the other hand, exemplified in Rights Respecting Schools, described below, contributes politically to developing new and inclusive visions and understandings of what it means to be a citizen in the multicultural, multifaith and multinational communities that constitute the UK. Where it promotes national cosmopolitanism (Staeheli and Hammett, 2013) or postnational citizenship (Soysal, 1994) citizenship education has an important role in mitigating the xenophobic and nationalist agendas that found expression in the 2016 referendum on EU membership. It can legitimately promote identification both with the procedural values of the UK and with a pride in diversity as the essence of democracy.

\section{Citizenship education in England and national identity}

There is no tradition in schools in England of saluting the national flag or singing the national anthem. There is no pledge of allegiance as in the USA. Whilst there is little privileging of the national flag, it is not uncommon to see an international display of flags symbolising countries of origin of the pupil population or celebrating an 
and global perspectives Geografiska Annaler: Series B, Human Geography. Paper as accepted.

international sporting occasion such as the Olympic Games or the World Cup. Reporting on her visits to observe citizenship education in schools in England, a US scholar noted:

I saw no signs of nationalism. Whether or not the schools identified themselves as global, I never saw a national flag, never heard a national anthem, and never saw a photo of a national political leader or monarch displayed. Further, no teacher with whom I spoke mentioned teaching citizenship as a legal status. Rather, they seemed most comfortable preparing global citizens (Hahn, 2015, 113/4).

This observation is indicative of some schools adopting a culture of depoliticised and tepid internationalism, with an intension to be inclusive by avoiding controversy or conflict. A similar situation has been identified in South Africa (Staeheli and Hammett, 2013).

The national curriculum for England, first introduced following the (great) Education Act of 1988, still exists, in spite of the fact that it is no longer mandatory for academy, free and private schools. Local Authority maintained schools where the national curriculum applies are a minority, even of publicly funded schools. The formal programmes of study for Citizenship were last revised in 2013 under the UK's Conservative-led coalition government. They have been pared back in recognition of the limited time likely to be available, probably one hour a week for some weeks of the year. However, a new element was introduced in 2013, namely the knowledge necessary to enable students 'to manage their money on a day-to-day basis, and plan for future financial needs' (DfE, 2013). This focus on personal finance leaves even less time for the social and political dimensions of citizenship. 
and global perspectives Geografiska Annaler: Series B, Human Geography. Paper as accepted.

The programme of study for citizenship presents democratic structures and Parliament as a given, not as the result of landmark events such as the English Civil War, the British revolution of 1688 and continuing struggles for suffrage and for equalities. Although the UK does not have a written constitution, at Key Stage 4 (14-16 year olds) are to be taught about:

parliamentary democracy and the key elements of the constitution of the United Kingdom, including the power of government, the role of citizens and Parliament in holding those in power to account, and the different roles of the executive, legislature and judiciary and a free press (DfE, 2013)

Constitutional principles, such as democracy and 'holding those in power to account' have to be deduced from this formulation, though they may be made more accessible to teachers in textbooks and other support materials published by commercial publishers and NGOs. There is no emphasis on the fact that that these principles were achieved through conflict and struggle.

In the absence of a constitution, the UK does have a formal binding commitment in international law to adhere to the standards set out in the European Convention on Human Rights (ECHR) and abide by the rulings of its court. Although there is provision at Key Stage 4 (14-16 year olds) for teaching about 'human rights and international law' this is in the context of 'the United Kingdom's relations with the rest of Europe'. Such a formulation is suggestive of the UK being an outsider rather than a core member of the EU and this in spite of the fact that the programme of study was published three years before the referendum decision to leave the EU. The ECHR is administered by the 47 member Council of Europe, not the EU, but the formulation 'the rest of Europe' is suggestive of the word Europe having been toxic in political discourse for perhaps three 
and global perspectives Geografiska Annaler: Series B, Human Geography. Paper as accepted.

decades. In spite of the fact that many schools in England have benefitted from and eagerly participate in EU- funded exchange and curriculum development programmes, such as Erasmus, the Citizenship programme of study offers no encouragement to attempt to promote a European identity. In fact some empirical research suggests that attempts in England to promote an identification with or even understanding of Europe have been an uphill struggle. Evidence from one European collaborative education project found that being introduced to the work of EU institutions is perceived as dull by students who nonetheless may be happy to enliven their lesson by expressing antiEuropean prejudices in the hope of generating arguments (Osler, 2011).

At Key Stage 3 (11-14 year olds) there is an intriguing reference to pupils being taught about 'the precious liberties enjoyed by the citizens of the United Kingdom'. This does appear to be an attempt to suggest that UK citizens are privileged in having enjoyment of liberties in a way that others may not. The phrase 'precious liberties' is not drawn from a well-known quotation. It is an original but archaic phrase suggestive of fragility and therefore of the need to protect the valued freedoms. Again there is no suggestion that the liberties have been achieved through struggle, not even a reference to Magna Carta. A joined up approach to the Citizenship curriculum might recognise that the 'precious liberties' are protected in international law and domestic law by the UK Human Rights Act of 1998. If the liberties are precious, so is the Act.

The vestigial programmes of study for Citizenship provide space for the discussion of the roles of key institutions such as: democratic government; Parliament; the monarch; political parties; the justice system; the police; courts and tribunals; (the rest of) Europe; the Commonwealth; the United Nations. Whilst not everything can be included, some of the most important institutions by size of budget as well perceived 
and global perspectives Geografiska Annaler: Series B, Human Geography. Paper as accepted.

value are omitted in spite of an injunction to teach about 'how public money is raised and spent'. In fact there is nothing on several institutions that help to create and sustain a sense of national identity such as: the armed forces, the NHS, education and the BBC.

Whilst England has an Established Church, and its doctrines and beliefs may figure in the religious education curriculum, its political, social and possible moral significance are omitted from Citizenship. Desirable attributes of citizenship, promoted in the programme of study include: volunteering; other forms of responsible activity; thinking critically and debating political questions; managing money and budgeting; presenting reasoned arguments; taking informed action; working together to improve communities, including opportunities to participate in school-based activities. There is, however, no explicit ideological, theoretical or moral framework or rationale for engaging in such activities.

\section{Values that Underpin Public Life in the UK}

The British culture of government and democracy has rested on creative ambiguity (Starkey, 2008). Principles are often assumed rather than made explicit. Conflict is avoided by not defining key concepts such as democracy or the constitution too carefully. Since the UK has no formal written constitution, there is no definitive and consensual account of national values in the UK. The words of the national anthem provide little indication of a possible political sense of direction or guiding principles. This ambiguity also affects Citizenship in England. The programme of study carefully avoids an emphasis on national and also European symbols and institutions. The political literacy model of Citizenship that is the legacy of Crick eschews flag waving nationalism. Consequently when the British government and its security services 
and global perspectives Geografiska Annaler: Series B, Human Geography. Paper as accepted.

determined that the best way to counter radical Islamist narratives that had led to terrorist acts was to promote a national identity based on a commitment to national values, Citizenship was side-lined.

Rather than promoting a minimalist definition of national values (FBVs), British authorities might have looked at the standards and principles underpinning international agreements and treaties entered into by successive governments. These arguably exemplify the values that underpin public life in the UK. Morsink (1999) identified some 200 human rights instruments, including declarations, resolutions, guidelines, conventions, and covenants that make up a body of international human rights law. The UK government is signatory to many of these instruments that are translated into legal and policy instruments at national level. The most powerful instruments are conventions and covenants, since, under the Vienna Convention on the Law of Treaties (1980), signatory governments are legally bound to observe their provisions. They agree to respect, protect and fulfil human rights. In other words, they refrain from restricting rights (respect); ensure legal security for the enjoyment of human rights (protect); and put in place measures that promote human rights (fulfil) (Osler and Starkey, 2010).

If looking for a definition of procedural standards and principles that command respect across the political and judicial cultures of the UK, there is a strong case to be made for starting with the Human Rights Act 1998. This national UK legislation requires public bodies including the Government itself, the police, the judiciary and local authorities to be mindful of the rights guaranteed under the European Convention on Human Rights (ECHR). In practice this means, amongst other things, a public commitment to fair treatment and due process, non-discrimination in rights and a concern for dignity and the respect of individuals, whether national citizens or not. 
and global perspectives Geografiska Annaler: Series B, Human Geography. Paper as accepted.

Whilst the rights under the ECHR are justiciable and therefore a limited set of rights, the ECHR acknowledges its origins in the principles enshrined in the Universal Declaration of Human Rights. In other words, the Human Rights Act requires public bodies to be mindful of human rights such that they help to create a national culture of respect for human rights.

Another human rights convention to which the UK is signatory and that is particularly relevant to schools and the education system is the 1989 UN Convention on the Rights of the Child (CRC). This convention is notable for having been ratified by virtually every member of the United Nations and can thus be considered to embody universal principles for the ways in which young people under the age of 18 are entitled to be perceived, be provided for and protected and to exercise agency. Governments that are signatories to the $\mathrm{CRC}$ are obliged to report to the United Nations on the extent to which they respect, protect and fulfil children's rights (Long, 2016). As with the Human Rights Act, UK Governments both Conservative and Labour have enacted national legislation to implement undertakings in the CRC, namely the Children Act 1989 and the Children Act 2004. The international principles of the CRC become embedded in national regulations and administrative apparatus.

The essence of universal human rights is that they are independent of place. The founder of the NGO Save the Children, Eglantyne Jebb, who drafted the Declaration of the Rights of the Child in 1923, promoted a conception of needy children that was independent of nationality. Based on her experience working with other humanitarian organisations in several different countries in continental Europe following the First World War she determined that child refugees and displaced orphans had a right to protection whatever their nationality. Similarly and almost simultaneously, René Cassin 
and global perspectives Geografiska Annaler: Series B, Human Geography. Paper as accepted.

came to the same conclusions but about adults. As a lawyer representing displaced French World War I veterans he led a campaign to ensure that they were not denied their rights to pensions simply because they did not hold formal citizenship status in their new country of residence (Winter, 2006). Considering that they were clearly members of the communities where they lived, Cassin argued that domicile as well as citizenship should be a source of rights. In other words, rights attach to individuals, wherever they live; they are not the gift of the nation-state. Cassin used this insight in his substantial contribution to the drafting of the UDHR. The concept of human rights as opposed to the rights of the citizen derives from this insight that rights should belong to the individual as human being rather than being dependent on the status of citizen of a nation-state (Osler and Starkey, 2010).

Although human rights pertain to individuals, States have the responsibility to uphold them and States also receive legitimacy in the international order as signatories of human rights instruments (Perugini and Gordon, 2015; Osler, 2016). However, the close relationship between international or universal standards and national legislation and the culture of national public life has rarely been invoked by political leaders in the UK. Instead, there has been a series of rhetorical interventions promoting a nationalised conception of citizenship that tends to promote an essentialised national identity, sometimes referred to as Britishness (Osler, 2008; Richardson, 2015). This may be part of a more general trend towards individualism and nostalgic national patriotism that has become a powerful political discourse in many national contexts in the $21^{\text {st }}$ century and risks spreading to schools and education systems (Mitchell 2003).

\section{Citizenship and diversity}


and global perspectives Geografiska Annaler: Series B, Human Geography. Paper as accepted.

Following the London terrorist bombings of 2005, the Department for Education and Skills commissioned a review of the citizenship curriculum with the intention that it might be able to contribute to the Government's security agenda of preventing the radicalisation of young people who might then be drawn to terrorism. The Ajegbo Review, named after the distinguished London head who chaired the drafting group, recommended that citizenship education should incorporate a new strand based on identity and diversity, living together in the UK (Department for Education and Skills, 2007).

One of the main insights of the review was a recognition that a stress on national identity, or Britishness, was not appropriate in a context where young people come from families where many national backgrounds are salient and where they develop multiple and flexible identities (Ong, 1999, 2004; Osler and Starkey, 2005). The review quotes approvingly a statement made in a consultation with Professor Bhikhu Parekh that: 'we can refer to British shared values only in so far as we can say that the UK has decided to commit to these values and in this sense take ownership of them' (Department for Education and Skills, 2007, 93; Osler, 2008). In other words, British values are made explicit in the act of ratifying international conventions.

As Frazer presciently noted: 'the emphasis on 'values', in the UK context, is an explicitly depoliticising move in the debate about political education' $(2003,65)$. The Citizenship programmes of study, as noted above, provide opportunities to study topics including democracy and human rights and to discuss issues and tensions inherent in operationalising them in practice. However, approaching these topics through the school ethos of social, moral, spiritual and cultural opportunities (SMSC) is likely to be diffuse, sporadic and apolitical. SMSC is an overall aim for a school rather than 
and global perspectives Geografiska Annaler: Series B, Human Geography. Paper as accepted.

constituting its formal curriculum. Whereas Citizenship has specific content that covers all the dimensions listed as fundamental British values (FBVs), an approach through SMSC demands that schools interrogate their curriculum, in the broad sense of all the planned activities of the school in order to identify evidence that they are complying with the guidance. In so doing they may engage in discussions of 'Britishness' in which the teachers and consequently the students have no points of anchor or conceptual frameworks to help co-construct knowledge and understandings of what the concept means politically (Osler, 2011; Keddie, 2014). Commercial companies offering schools advice and resources such as posters to promote FBVs in some cases propose a quaintly touristic vision including red phone boxes, fish and chips, teapots and the Queen (Moncrieffe and Moncrieffe, 2017). In other words there is confusion between values such as democracy and symbols that have become associated with an essentialised and nostalgic view of Britain. In fact it can be argued that a focus on FBVs may actually undermine adhesion to human rights by drawing attention away from the international, European and universal basis of human rights law (Struthers, 2016).

\section{Education for cosmopolitan citizenship}

The demographic realities particularly of urban schools in England and many other countries challenge conceptions of citizenship as equating solely to a civic relationship to a particular nation-state (Osler and Starkey, 2003). Although governments are likely to define citizenship in terms of nationality, in fact to nationalise citizenship, this political, sociological and moral concept has other powerful dimensions. For educators in a globalising world a definition of citizenship as a feeling, a status and a practice extends the import ant concept of citizenship to children and to non-nationals (Osler and 
and global perspectives Geografiska Annaler: Series B, Human Geography. Paper as accepted.

Starkey, 2005). The feeling is of belonging to a community and communities. The status is both a legal status that may include nationality but also a moral status as human being entitled to human rights. The practice of citizenship involves engaging with others particularly in activities that are intended to improve social and ecological living conditions. All these dimensions of citizenship can be realised at levels from the very local neighbourhood or village to the global. The status with respect to human rights depends on being aware of universal human rights as an entitlement, in the context of all other human beings having the same entitlement.

This definition of citizenship as feeling, status and practice challenges assumptions that citizenship education is just intended to inform learners of the political and legal structures that support a status quo seen in national terms. Citizenship as a status references international obligations and provides a transnational perspective that is best characterised as cosmopolitan. At its most basic, the cosmopolitan citizen is one who 'views herself as a citizen of a world community based on common human values' (Anderson-Gold, 2001, 1). The primacy of the national community is challenged by recognition of identities within local and transnational communities. Indeed the notion of community is extended so that its limiting case is a community composed of all human beings (Starkey, 2012). Education for cosmopolitan citizenship invites a reimagining of the nation as cosmopolitan where its citizens are all connected to people in a world community extending beyond national boundaries. This has been theorised by Beck as nations developing "internal globalization, globalization from within the national societies" in a process of cosmopolitanization (2002, 17 original emphasis).

Understanding citizenship as independent of nationality, where all young people in schools can see themselves as citizens, is illustrated by research based on 
and global perspectives Geografiska Annaler: Series B, Human Geography. Paper as accepted.

conversations with young people in an urban area (Osler and Starkey, 2005). Whilst young people in rural areas of England may still have difficulty in recognising their communities as diverse and inextricably linked to other places and communities across the world (Weller, 2007), evidence from urban youth suggests that cosmopolitan perspectives are no longer simply the hallmark of a global elite. Migrant populations, some of whose members may be amongst the most economically deprived, have, by definition, identities that embrace communities beyond the UK.

One qualitative research study with young people in a British city noted for its diversity, illustrates ways in which the informants were often connected across several continents (Osler and Starkey, 2005). One British-born teenager, who was not unusual in her school, expressed feelings of local and national belonging but also identified on her mother's side with family in India and on her father's side with Uganda. Another informant, whose mother was born in Malaysia and whose father was from Zimbabwe kept in touch with grandparents in India, Both these young people were connected across several continents by relationships with family members and awareness of the geographical histories of their parents and grandparents. Several interviewees expressed a sense of privilege that they were living in a multicultural city and pride in a community that recognises many heritage languages and cultures but also looks to the future.

Globalisation has created conditions where people, including young people, identify with a range of places and communities, within and beyond their locality and the UK. Senses of belonging are often far more grounded in the neighbourhood or city than in the 'imagined community' of the nation (Anderson, 1991) though ideological 
and global perspectives Geografiska Annaler: Series B, Human Geography. Paper as accepted.

nationalists may attempt to insist on a hierarchy of belongings privileging the nation. In fact a sense of belonging to a place or nation is often contingent, varying with the context. Moreover, having connections by family, migration or interest to various geographically distant places facilitates a cosmopolitan perspective, namely to identify as members of a world community. Since communities are defined by holding feelings and standards in common, a world community references what the United Nations defines as the universal values of human rights. In this context, a major challenge for schools is to reimagine the nation as being constructed from multiple and cosmopolitan narratives (Osler, 2008).

Narratives of belonging do not necessarily require a national point of reference. An interesting initiative brought together university students in the UK, who are almost all internal migrants, with refugees living in the city where the students study. Sharing a sense of being a newcomer to a community provided important benefits for both parties, and also cemented a sense of community of place. The students in this project are known as befrienders. One student informant joined the project from a wish to extend her circle of acquaintances beyond the university. She used her own vulnerability as a newcomer to the city to find common ground and community with migrants with the status of refugee. Together they worked on practical issues of daily living to mutual benefit, described by the student as 'investing in a place' and aiming to make it 'a good and inclusive place to live' (Askins, 2016, 521).

Creating new senses of community with recent arrivals can be facilitated by those with skills and experience that enable them to mediate between cultures, and open access to new or strange social contexts. This role has been named bridge figure (Zuckerman, 2013). Askins (2016) gives the example of another student bridge figure 
and global perspectives Geografiska Annaler: Series B, Human Geography. Paper as accepted.

who took a more explicitly politically engaged view when she argued that working with migrants in your own community connects you to communities and events elsewhere. Both the students in these examples extend their notion of citizenship, seeing it as a practice where nationality is irrelevant. They see scope for action or acts of citizenship (Isin, 2008) at a local level that may contribute to a national collective effort, but there is no evidence that the national dimension is salient.

Education for cosmopolitan citizenship accepts the realities of multiple and flexible identities (Appiah, 2006; Sen, 2006; Ong, 2009). As Hahn observes:

One can be a member of cultural communities, a resident of a nation state, and may also perceive membership in a diasporic or global society. Furthermore, many individuals are transnational citizens. Refugees, migrant workers, immigrants, or people employed by transnational companies requiring their frequent relocation and their children maintain attachments to multiple communities $(2015,96)$.

Any national dimension of citizenship is not necessarily more salient than other situated perspectives. Indeed it has been cogently argued by Martha Nussbaum that too strong an emphasis on the national is actually undemocratic:

One of the greatest barriers to rational deliberation in politics is the unexamined feeling that one's own preferences and ways are neutral and natural. An education that takes national boundaries as morally salient too often reinforces this kind of irrationality, by lending to what is an accident of history a false air of moral weight and glory $(1996,11)$.

Democracy, as well as the law, still references and values rationality, even after the populist rejections of the status quo in the elections in UK, USA and Italy in 2016. Consequently, an education that promotes an emotional rather than rational adherence to the nation undermines the capacity to deliberate freely and therefore reduces the space for democratic debate. An emotional patriotism is a powerful moral impulse that 
and global perspectives Geografiska Annaler: Series B, Human Geography. Paper as accepted.

may combine with other religious or ideological sources of morality to exclude critical or minority voices.

Education for cosmopolitan citizenship, on the other hand, leaves individuals free to determine the extent to which they wish to identify with a single nation-state. It relativises the moral salience of the nation, allowing space for considering the performance of particular governments and institutions against the universal standards set out in human rights instruments.

\section{Rights Respecting Schools}

If there is one major education project in the UK that intends to promote understandings of cosmopolitan citizenship, it is UNICEF UK's Rights Respecting Schools Award. The NGO claims on its website that this programme has been adopted in 4000 schools attended by 1.4 million children ${ }^{2}$. The Rights Respecting School Award (RRSA) is a national award scheme started in 2004 that aims to embed the principles and values of the United Nations Convention on the Rights of the Child (CRC) in the ethos and curriculum of schools. In summary the programme aims that:

Everyone in the school learns that children and young people have rights under the United Nations Convention on the Rights of the Child (CRC) and that everyone is responsible for respecting the rights of others. The ethos created demonstrates to children the inclusiveness of a rights-respecting school and paves the way to greater participation in the life of the community (Sebba and Robinson, 2010, 8).

\footnotetext{
${ }^{2}$ https://www.unicef.org.uk/rights-respecting-schools/
} 
and global perspectives Geografiska Annaler: Series B, Human Geography. Paper as accepted.

Schools receive the award when they can demonstrate that the CRC is known and understood by their leadership and integrated into management, curriculum, and classroom climate. Pupil participation in decision-making is also a criterion for the award. Schools can work towards either a Level One or a Level Two award depending on how well integrated rights are within the school. Level One is awarded when they can demonstrate that they have shown good progress in four dimensions. Level Two is achieved when they can demonstrate that they have 'fully embedded' the principles and values of the CRC.

The rapid expansion of the scheme, more than doubling the number of schools involved between 2010 and 2016, together with positive evaluations by academics (Sebba and Robinson, 2010) and inspectors is indicative of an approach to developing school ethos that heads, teachers and governing bodies as well as students find attractive, accessible and meaningful. This confirms findings from an earlier study of a similar programme in Hampshire (Howe and Covell, 2005). Indeed there are even claims that such programmes can overcome educational disadvantage (Covell, Howe, and Polegato, 2011).

The extracts from published Ofsted school inspection reports displayed on the NGO's website include:

Students respect each other's backgrounds and points of view so that the school operates as a cohesive society. Their understanding of the wider world is promoted well, for example, in the recent work to achieve the UNICEF Rights Respecting status (Howard School, Medway Nov 2013).

Students' spiritual, moral, social and cultural development is very well supported by the school's accreditation as a 'UNICEF Rights Respecting School'. The school is 
and global perspectives Geografiska Annaler: Series B, Human Geography. Paper as accepted.

successful at preparing students for life in a multicultural society... (Harrow Way

Community School, Hampshire July 2013).

Discrimination of any kind is not tolerated, ensuring the full inclusion of all pupils. The school has a specific school policy of being a 'rights-respecting' school (Dosthill Primary School, Staffordshire, March 2013).

The quotations from inspectors have been picked out by the NGO as evidence that the RRSA award conforms to mainstream expectations of schools, where this is premised on community cohesion, whole school ethos (SMSC) and an all-purpose 'inclusion' agenda. In fact there have been critical appraisals of the way the programme has been implemented in schools, mainly based on schools using respect for rights as a means to behaviour management (Howe and Covell, 2011; Mejias and Starkey, 2012; Trivers and Starkey, 2012). That said, the basic principle of referencing the CRC as a source of moral authority in schools has not been challenged.

It is perhaps instructive to note that whereas the Rights Respecting Schools Award was supported until 2010 by the education ministry (Department for Children, Schools and Families, DCSF), government funding under Coalition $(2010$ - 2015) and then Conservative (2015 - ) governments has been mostly provided by the Department for International Development (DfID) particularly through the Global Learning Programme that operates through a consortium led by the private sector education conglomerate Pearson ${ }^{3}$. This switch of funding is indicative of a Government perspective that instrumentalises the role of education in relation to the anti-extremism Prevent strategy. Education for cosmopolitan citizenship remains unfunded whilst

\footnotetext{
${ }^{3}$ see: http://glp.globaldimension.org.uk/
} 
and global perspectives Geografiska Annaler: Series B, Human Geography. Paper as accepted.

understandings of children's human rights are supported but as part of a humanitarian concern for other countries.

The Fundamental British Values (FBV) mandated to be taught in maintained and private schools in England, all find expression in the UN Convention on the Rights of the Child (CRC). The FBV formula: 'democracy, the rule of law, individual liberty and mutual respect and tolerance of different faiths and beliefs' (UK Government Home Department, 2011, 35 and 107) matches the affirmation about education in the preamble to the CRC:

Considering that the child should be fully prepared to live an individual life in society, and brought up in the spirit of the ideals proclaimed in the Charter of the United Nations, and in particular in the spirit of peace, dignity, tolerance, freedom, equality and solidarity, The CRC also references the Universal Declaration of Human Rights where a 'democratic society' is a given (article 29).

Starting from their commitment to teach and uphold the universal standards and principles of the UN Convention on the Rights of the Child, schools engaging with the Rights Respecting Schools Award respect the narrower target that is so-called Fundamental British Values (FBVs). Schools are hubs of wider social networks (Neal, Vincent, and Iqbal, 2016), and RRSA schools, respecting global human rights standards as well as national expectations, are in a position to acknowledge feelings of belonging in multiple places. However, where schools simply attempt to meet obligations to follow FBVs it is quite possible that they will not promote human rights or encourage students to develop multiple and cosmopolitan identities. 
and global perspectives Geografiska Annaler: Series B, Human Geography. Paper as accepted.

\section{Conclusion}

A focus on FBVs can be read as one element in 'an increasingly elaborate regime of state and privatised infrastructures that monitor and manage the migrant as a counterfeit citizen' (Hall, 2015: 854). National governments prioritise the protection of their citizens, but by equating citizenship and nationality they may effectively discourage a feeling of belonging to a national community for those without nationality status. One interpretation of the UK's 2016 referendum on EU membership is that a substantial part of the electorate disapproved of non-UK EU citizens having the same entitlements as UK nationals. Whereas the capital city and other large multicultural urban centres voted in favour of retaining the free movement of citizens across the EU space, there was a slight overall majority for reverting to an explicitly nationalist status for the UK (Wheatley, 2016). This is the political context in which successive UK governments have promoted the anti-terrorist Prevent strategy as responding to ideologies that disrespect the community of a nation whose values are broadly liberal and inclusive. Such an idealised view of the nation is easily perceived as being in tension with political and sociological realities.

The Rights Respecting Schools Award programme, supported by the UK government through International Development funding, is based on cosmopolitan perspectives in direct tension with the Fundamental British Values agenda of the Education Department in support of the security services. A focus on FBVs is an attempt to promote the salience of national boundaries. The Rights Respecting Schools Award programme takes advantage of citizenship education as a space on the curriculum where issues of human rights and identities can be discussed and new meanings co-constructed. Rhetorical and graphic images of a UK defined largely by its 
and global perspectives Geografiska Annaler: Series B, Human Geography. Paper as accepted.

heritage can be analysed, discussed and challenged. The RRSA provides incentives to develop education for cosmopolitan citizenship that links individuals to communities at scales from the very local to the global in a way that relativises the national dimension.

The legal obligation to promote Fundamental British Values may be an attempt to depoliticise discussion of the values and standards that underpin public life in the UK and the extent to which they are upheld. FBVs encourage an unquestioning view of the nation as the most salient community. The Rights Respecting Schools Award programme, on the other hand, provides schools with opportunities to continue to develop political literacy and commit to universal human rights principles and standards that problematize mythical identifications of values with a single or specific place.

This article brings together a variety of perspectives including legal, political, sociological and geographical in an attempt to show how opportunities for education for cosmopolitan citizenship are now a site of struggle. A poorly construed and little understood policy of strongly emphasising so-called Fundamental British Values may conflict with the right under article 29 of the CRC for children to develop respect for their own cultural identities and values as well as national values. The same article guarantees the right to learn about human rights. Rights Respecting Schools provide space for political literacy and cosmopolitan perspectives whilst also promoting democracy, the rule of law, individual liberty and mutual respect and tolerance of different faiths and beliefs, namely the Fundamental British Values. Armed with understandings of universal human rights and drawing on family narratives that transcend national borders, children and teachers may develop cosmopolitan perspectives that constructively confront limiting accounts of British identities. The tension between Fundamental British Values and Citizenship reflects the political 
debate as to whether the struggle against terrorism requires discussion of political options rather than the closing of space for considering identities and diversity in the context of living together in the UK.

\section{References}

Anderson, B. 1991. Imagined Communities: Reflections on the Origin and Spread of Nationalism (revised edition). London: Verso.

Arthur, J. 2003. Education with Character: The Moral Economy of Schooling. London: Routledge.

Askins, K. 2016. "Emotional Citizenry: everyday geographies of befriending, belonging and intercultural encounter". Transactions of the Institute of British Geographers, 41: 515-527.

Banks, J. A. (Ed.). 2017. Citizenship Education and Global Migration: Implications for Theory, Research, and Teaching. Washington, DC: American Educational Research Association.

Beck, U. 2002. “The Cosmopolitan Society and its Enemies”. Theory, Culture and Society, 19 (1-2): 17-44.

Covell, K., Howe, R. B., and Polegato, J. L. 2011. “Children's human rights education as a counter to social disadvantage: a case study from England". Educational Research, 53(2):193 - 206. 
Department for Education. 2014. "Promoting fundamental British values as part of SMSC in schools: Departmental advice for maintained schools". London: Department for Education.

Department for Education and Skills. 2007. "Diversity and Citizenship: curriculum review (Ajegbo review)”. London: DfES.

Dewey, J. [1916] 2002. "Democracy and Education: an introduction to the philosophy of education”. In S. J. Maxcy (Ed.), John Dewey and American Education Vol. 3. Bristol: Thoemmes.

Elton-Chalcraft, S., V. Lander, L.Revell, D. Warner, and L. Whitworth 2017. "To Promote, or Not to Promote Fundamental British Values? Teachers' Standards, Diversity and Teacher Education." British Educational Research Journal 43 (1): $29-48$.

Frazer, E. 2003. “Citizenship Education: anti-political culture and political education in Britain”. In Education for Democratic Citizenship: issues of theory and practice edited by A. Lockyer, B. Crick and J. Annette , 64-77. Aldershot: Ashgate.

Freire, P. [1970] 1996. Pedagogy of the Oppressed. Harmondsworth: Penguin.

Green, A. 1990. Education and State Formation: The Rise of Education Systems in England, France and the USA. London: Palgrave Macmillan UK.

Green, A. 2013. Education and State Formation: Europe, East Asia and the USA (2nd edition). Basingstoke: Palgrave Macmillan.

Gutmann, A. 2003. Identity in Democracy. Woodstock, UK: Princeton University Press. 
Hahn, C. 2015. "Teachers' perceptions of education for democratic citizenship in schools with transnational youth: A comparative study in the UK and Denmark". Research in Comparative and International Education 10 (1): $95-119$

Hall, S. 2015. "Migrant Urbanisms: Ordinary Cities and Everyday Resistance." Sociology 49, (5): 853-69.

Halstead, J. M., and M.Taylor, 2002. Moral and citizenship education. London: RoutledgeFalmer.

Haydon, G. 2007. Values in Education. London: Continuum.

Home Office. 2001. Community Cohesion: A Report of the Independent Review Team Chaired by Ted Cantle. London: TSO.

Howe, R. B. and K.Covell, 2005. Empowering Children: Children's Rights Education as a Pathway to Citizenship. Toronto, University of Toronto Press.

Howe, R. B. and K.Covell, 2010. "Miseducating children about their rights". Education, Citizenship and Social Justice, 5 (2): 91 -102.

Isin, E.F. 2008. “Theorizing acts of citizenship”. In Acts of Citizenship edited by E.F. Isin and G.M. Nielsen. London: Zed Books.

Jerome, L. 2012. England's Citizenship Education Experiment: State, School and Student Perspectives. London: Continuum.

Keddie, A. 2014. "The politics of Britishness: multiculturalism, schooling and social cohesion”. British Educational Research Journal, 40 (3): 539-554.

Kymlicka, W. 2003 "Multicultural States and Intercultural Citizens." Theory and Research in Education 1 (2): 147-69. 
and global perspectives Geografiska Annaler: Series B, Human Geography. Paper as accepted.

Long, A. 2016. UN Convention on the Rights of the Child: a brief guide. Briefing Paper 7721. London: House of Commons Library.

Mejias, S., and H. Starkey. 2012. “Critical Citizens or Neoliberal Consumers? Utopian Visions and Pragmatic Uses of Human Rights Education in a Secondary School in England”. In Politics, Participation and Power Relations: Transdisciplinary Approaches to Critical Citizenship in the Classroom and Community edited by R. C. Mitchell and S. A. Moore, 119-136. Rotterdam: Sense.

Mitchell, K. 2003. "Educating the national citizen in neoliberal times: from the multicultural self to the strategic cosmopolitan". Transactions of the Institute of British Geographers, 28, 387-403.

Moncrieffe, M., and Moncrieffe, A. 2017. "British values: What are the most prominent images used for display boards in the primary school?" Retrieved from https://www.bera.ac.uk/blog/examining-the-representation-of-fundamental$\underline{\text { british-values }}$

Morsink, J. 1999. The Universal Declaration of Human Rights: origins, drafting and intent. Philadelphia: University of Pennsylvania Press.

Neal, S., C. Vincent, and H. Iqbal, 2016. "Extended Encounters in Primary School Worlds: Shared Social Resource, Connective Spaces and Sustained Conviviality in Socially and Ethnically Complex Urban Geographies." Journal of Intercultural Studies 37 (5): 464-80.

Nussbaum, M. C., 1996. For love of country: debating the limits of patriotism. Boston: Beacon Press. 
Nussbaum, M. C. 2012. The New Religious Intolerance: overcoming the politics of fear in an anxious age. Cambridge, Mass. and London: Belknap Press.

Ong, A. 1999. Flexible Citizenship: The Cultural Logics of Transnationality. Durham NC and London: Duke University Press.

Ong, A. 2004. "Higher Learning: Educational Availability and Flexible Citizenship in Global Space”. In Diversity and Citizenship Education: global perspectives edited by J. A. Banks, 49-70. San Fancisco: Jossey-Bass.

Osler, A. 2008. "Citizenship education and the Ajegbo report: re-imagining a cosmopolitan nation". London Review of Education, 6 (1): 9 - 23.

Osler, A. 2011. "Teacher interpretations of citizenship education: national identity, cosmopolitan ideals, and political realities". Journal of Curriculum Studies, 43 (1): 1-24.

Osler, A. 2016. Human Rights and Schooling: An ethical framework for teaching social justice. New York NY: Teachers College Press.

Osler, A., and Starkey, H. 2001. "Citizenship Education and National Identities in France and England: inclusive or exclusive?" Oxford Review of Education, 27 (2): 287-305.

Osler, A., and Starkey, H. 2003. "Learning for Cosmopolitan Citizenship: theoretical debates and young people's experiences”. Educational Review, 55 (3): 243-254.

Osler, A., and Starkey, H. 2005. Changing Citizenship: democracy and inclusion in education. Maidenhead: Open University Press.

Osler, A., and Starkey, H. 2009. "Citizenship Education in France and England: contrasting approaches to national identity and diversity". In The Routledge 
International Companion to Multicultural Education edited by J. A. Banks 334347. New York: Routledge.

Osler, A., and Starkey, H. 2010. Teachers and Human Rights Education. Stoke-onTrent: Trentham.

Oxfam Development Education Programme. 2006. Education for global citizenship: a guide for schools. Oxford: Oxfam GB.

Perugini, N., and N. Gordon, 2015. The Human Right to Dominate. Oxford: OUP. Qualifications and Curriculum Authority. 1998. Education for Citizenship and the Teaching of Democracy in Schools: Final Report of the Advisory Group on Citizenship (the Crick Report). London: Qualifications and Curriculum Authority (QCA).

Richardson, R. 2015. “ British values and British identity: Muddles, mixtures, and ways ahead" London Review of Education 13 (2): 37-48.

Richardson, R., and B. Bolloten, 2014. “'Fundamental British Values' - origins, controversy, ways forward: a symposium". Race Equality Teaching, 32 (3): 920.

Sebba, J., and C. Robinson, 2010. Evaluation of UNICEF UK's Rights Respecting Schools Award. Final Report. London: UNICEF UK.

Staeheli, L. A. 2011. "Political geography: Where's citizenship?" Progress in Human Geography, 35 (3): 393-400.

Staeheli, L. and D. Hammett, 2013. "“For the Future of the Nation': Citizenship, Education and Divided Societies" Political Geography 32 (1): 32-41.

Starkey, H. 2008. "Diversity and Citizenship in the Curriculum”. London Review of Education, 6 (1): 3-8. 
Starkey, H. 2012. "Human rights, cosmopolitanism and utopias: implications for citizenship education". Cambridge Journal of Education, 42 (1): 21-35.

Struthers, A. 2016. “Teaching British Values in our Schools: but why not Human Rights Values?" Social and Legal Studies, 26 (1): 1-22.

Trivers, H., and Starkey, H. 2012. "The politics of critical citizenship education: human rights for conformity or emancipation?” In Politics, Participation and Power Relations: Transdisciplinary Approaches to Critical Citizenship in the Classroom and Community edited by R. C. Mitchell and S. A. Moore 137-152. Rotterdam: Sense.

UK Government Home Department. 2011. “Prevent Strategy”. London: TSO.

UNICEF UK. 2015. UNICEF UK Rights Respecting Schools Award: a good practice review. London: UNICEF UK.

Weller, S. 2007. Teenagers' Citizenship: experiences and education. London: Routledge

Wheatley, J. 2016. “Cleavage Structures and Dimensions of Ideology in English Politics: Evidence from Voting Advice Application Data”. Policy and Internet, 8 (4): 457-477.

Wood, J. 2016. To What Extent Does School Leadership Facilitate Community Cohesion for Students in an English Secondary School? PhD thesis, UCL Institute of Education, London.

Zuckerman, E. 2013. Digital Cosmopolitans: why we think the internet connects us, why it doesn't and how to rewire it. New York: Norton. 